\title{
El cine y la dermatología psiquiátrica. Stigmata
}

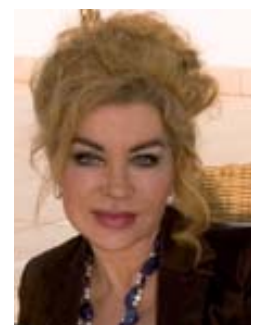

Aurora Guerra Tapia Profesora titular de Dermatología. Universidad Complutense de Madrid.

Jefa de la Sección de Dermatología. Hospital Universitario 12 de Octubre. Madrid.

Mire vuestra merced-respondió Sancho- que aquellos que alli se parecen no son gigantes, sino molinos de viento, y lo que en ellos parecen brazos son las aspas, que, volteadas del viento, hacen andar la piedra del molino. Miguel de Cervantes Saavedra, Don Quijote de la Mancha. Libro I, capítulo VIII

Cuando Joseph Beuys, el creador de las obras más caprichosas, controvertidas y corrosivas de la segunda mitad del siglo xx, afirmó que «el arte es la acción, es la vida», estaba enunciando la más apasionada definición de todas las que han intentado alcanzar su esencia: arte igual a vida.

Aunque todas las denominadas «bellas» lo pretenden —arquitectura, danza, escultura, música, pintura, literatura—, sólo el cine, el séptimo arte, lo consigue. Pero el ordinal que lo clasifica no le hace demasiada justicia. ¿Acaso no contiene sonidos armónicos como la música, imágenes estructuradas como la pintura, palabras encadenadas como la literatura, construcciones monumentales o exiguas como la arquitectura, volúmenes airosos o pesados como la escultura, movimientos tempestuosos o dulces como la danza?

El cine es el que con mayor precisión y amplitud simula la vida. Realidad o fantasía, retrato o metáfora, denigración o sublimación, todo ayuda a encontrar al hombre en cualquiera de sus perfiles, desmenuzarlo y volverlo a construir para, al menos durante un tiempo, formar parte de otras existencias que enriquezcan la nuestra.

Cuando nos sentamos delante de una pantalla con una visión de espectador aplicado, podemos descubrir, según nuestra intención e intereses, aspectos que pasan desapercibidos al resto de los espectadores. Una escrupulosa atención, o como diría Edward de Bono un pensamiento lateral, nos permitirá profundizar casi en cualquier cosa en la que pueda estar presente el ser humano. Y aunque pueda parecer difícil, también la dermatología psiquiátrica asoma en los filmes.

Esta especialidad de la medicina comprende, entre otras, aquellas enfermedades que, teniendo su origen en la mente, se manifiestan en la piel. Una de ellas es la dermatitis artefacta o trastorno facticio, clasificada en el Manual Diagnóstico y Estadístico de los Trastornos Mentales de la American Psychiatric Association (DSM IV) con el código F68.1 y el correspondiente [300.xx] de la Clasificación Internacional de Enfermedades $9^{a}$ revisión - Modificación Clínica (CIE $9-\mathrm{MC})^{1}$. 


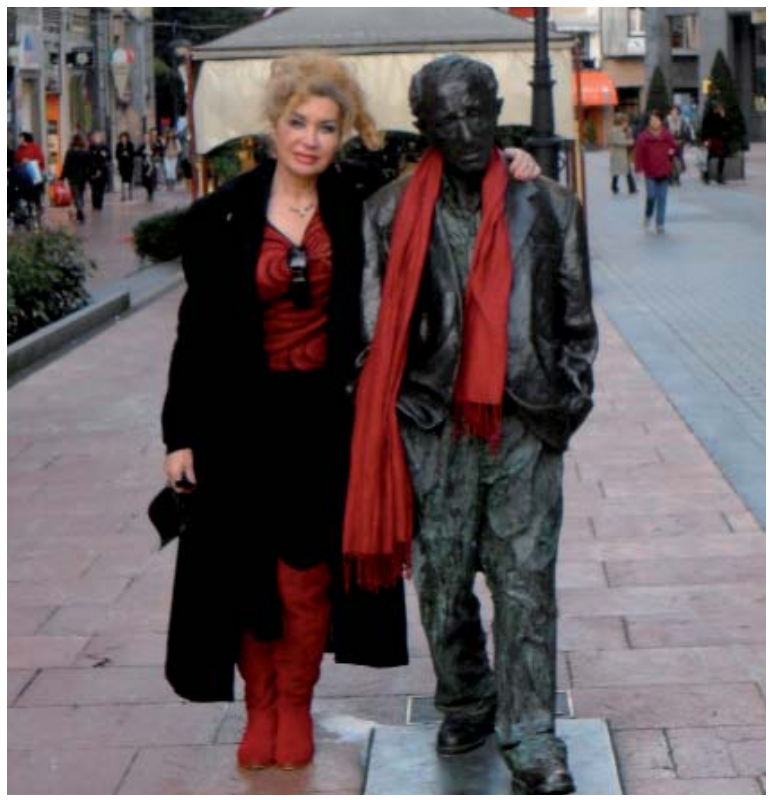

Aurora Guerra y Woody Allen paseando por las calles de Oviedo.

Los pacientes afectos de una dermatitis artefacta se producen intencionadamente daños en la piel de variadas clases. Frecuentemente son úlceras, que se localizan de forma simétrica en lugares accesibles a la mano dominante según sean diestros o zurdos. No son simuladores de una enfermedad para conseguir una ganancia económica o social, sino que cumplen con la necesidad emocional de llamar la atención para conseguir un bienestar psicológico. Ése es el quid del trastorno mental. Es más frecuente en mujeres con una personalidad débil, baja autoestima, a menudo en el borde de la normalidad intelectual, que tienen una intensa dificultad a la hora de expresar sus sentimientos ${ }^{2}$.

Todos estos requisitos los cumple Frankie Paige (Patricia Arquette), protagonista de la película estadounidense Stigmata, dirigida por Rupert Wainwright en 1999.

Es ella una joven peluquera de Pittsburg, superficial y sin problemas aparentes. Un día, tras recibir un misterioso paquete con un rosario y un escrito incomprensible de un sacerdote brasileño muerto en circunstancias sospechosas, comienza a padecer crisis nerviosas durante las que le aparecen heridas en los brazos, los pies y la cara. Acude a Urgencias en varias ocasiones, pero el proceso continúa. Tras una serie de episodios y el conocimiento casual de los mismos por la Iglesia católica, el Vaticano toma cartas en el asunto y envía al investigador Andrew Ciernan (Gabriel Byrne), que tiene por misión estudiar los fenómenos de explicación incierta que puedan tener una implicación religiosa.

No desvelaré el final de la historia.

Pero sí retrataré uno de los momentos en que Frankie acude a Urgencias. Mientras la médico explora las lesiones de la piel, se establece el siguiente diálogo:

Médico: Heridas lineales, de bordes limpios, como hechos con arma blanca, simétricas...

Frankie: ¿Cree que me lo he hecho yo misma?

Silencio.

Médico: ¿ Tiene algún problema importante en su vida? Frankie: El problema es que yo no soy importante.

Esas breves palabras de un acertado guionista parecen escritas por un experto en dermatología psiquiátrica, pues aun sin nombrarla, describen la enfermedad con toda claridad: dermatitis artefacta, trastorno facticio.

Pero unir este diálogo con los vericuetos que llevan al final feliz de la película nos resulta difícil. ¿Quiso decir el director que Frankie Paige era una enferma o que era una elegida por Dios? ¿Necesitaba un especialista en dermatología psiquiátrica, un exorcista o estaba destinada a la santificación?

La gran fortuna es que el cine no siempre es explícito. A veces, la palabra «fin» deja una ventana abierta para que el espectador complete la historia, la reinterprete, la reescriba, la haga suya.

Yo aquí he contado la mía: de mi mente a la piel del cine. Ahora viene su parte. Ver la película y opinar.

Y que siga el espectáculo.

\section{BIBLIOGRAFÍA}

1. López-Ibor Aliño JJ, Valdés Miyar M, dir. DSM-IV-TR. Manual diagnóstico y estadístico de los trastornos mentales. Texto revisado. Barcelona: Masson; 2002.

2. García Bustínduy MC, Rodríguez Pichardo A. Dermatitis artefactas. En: Guerra Tapia A, editora. Dermatología psiquiátrica: de la mente a la piel. Barcelona: Editorial Glosa; 2009. p. 63-78. 